\title{
Perception and Feedback of Undergraduate Medical Students on Medical Humanities
}

\author{
Article by Sachi Ojha ${ }^{1}$, Saboor Mateen ${ }^{2}$, Narendra Kumar Gupta ${ }^{3}$, Uma Gupta ${ }^{4}$, Farzana \\ Mahdi ${ }^{5}$, \\ ${ }^{1,2}$ MBBS, ${ }^{3,4,5}$ Dept of Medical Education and Technology \\ Era's Lucknow Medical College, Lucknow \\ Email: ${ }^{1}$ sachiojha@gmail.com, ${ }^{2}$ drsaboormateen@yahoo.com ${ }^{3}$ drnkgupta2000@gmail.com, ${ }^{4}$ \\ umankgupta@gmail.com, ${ }^{5}$ farzana.mahdi@gmail.com
}

\section{Introduction}

Medical humanities (MH) has been defined as "an interdisciplinary and increasingly international endeavor that draws on the creative and intellectual strengths of diverse disciplines including literature, art, creative writing, drama, film, music, philosophy, ethical decision making, anthropology, and history in pursuit of medical educational goals" [1] There is a great need of a "humane" doctor, with the understanding, assisted by interpretative ability and insight, and governed by ethical sensitivity, to apply this scientific evidence and skills to the individual patient.[2].

Empathy is a term difficult to define and it is said that in encompasses ethics, professionalism, communication skills and is much more and beyond these. Empathy describes the ability of the doctor to visualize and understand the patient's suffering, pain and perspective and then communicate back to him with the aim of healing him [3,4]. Empathy is a better understanding of and alleviation of human suffering and therefore it has cognitive, psychomotor as well as an affective component. It is essentially a quality which helps doctors gain an insight into the quality of pain being experienced by the patient and doing something active to allay his pain and solve his problem.

The good doctor must also develop sensitivity in his/her dealing with patients, which is based on knowledge of oneself and their own values and insight into the problems and contexts of patients' lives. Doctors need to be able to assimilate the scientific knowledge of disease and treatments with the understanding of the individual patient and to have good clinical judgment as to whatmight be of benefit to this patient with this particular problem at this point in his life [5]. This is the core problem for medical education to take on. In the last century the focus was largely on giving students the scientific knowledge and skills required of a doctor, but this isjust not enough. In 1993 The General Medical Council (GMC) recognized that medical education needed a radical change, humane doctor, rethink, and in their document, Tomorrow's Doctors,[6] recommended a greater focus on education, as opposed to training, in the undergraduate degree. The good doctor, as the GMC suggest, must be an educated doctor and this is one of the major areas where arts and humanities subjects might make a contribution.

Developing and maintaining an empathetic attitude towards patient is one of the important goals of medical education aiming at producing healers rather than mere physicians. The American Association of Medical Colleges has identified the development and enhancement of empathy in medical students as a key goal [7]. In recognition of its importance, many universities and medical colleges have awakened to the need of teaching empathy to medical students. Many medical schools offer a number of elective MH courses and students can select a particular one according to their interest and aptitude. However, the idea of $\mathrm{MH}$ is still relatively new in Asia. Studies have been conducted at Nepal and the authors found a positive approach of students towards the modules [8, 9]. Inadequate and miscommunication are the gaps in communication, while the problem of lack of communication between the doctors and the patients has long been recognized in India as well, still not much has been done remedial measures. MH is largely untouched in most of the medical schools and institutions in India. Also, we are not aware of any teaching modules or programmes on $\mathrm{MH}$ in the country. 
The study was therefore undertaken as a pilot project at Era's Lucknow Medical College when we tried to introduce sixth semester students to medical humanities. Among the specific objectives of the project were to understand empathy and its importance in medical care, know the effect of disease and sickness of a loved one on the family, be aware of the doctor-patient relationship. Paintings andphotographs as visuals play an important role in the project. Detailed participant feedback about the paintings used, the activities carried out using the paintings, problems with using visuals made available andtheir role future was also asked. Hence the present study was done to obtain detailed feedback about the use of photographs and paintings from the six semester student participants.

Aim of the study

1. To introduce sixth semester year medical student to the subject of empathy through Medical Humanities

2. To assess their receptivity to the subject

3. To obtain detailed feedback about the use of photographs and paintings

4. To sensitize them towards the role it plays in improving patient care.

\section{Methods}

The study in MH was used undertaken as a pilot project at Department of Medical Education at Era's Lucknow Medical College.

The following steps were followed.

1. In the first session, students were explained the definition, meaning, scope and purpose of $\mathrm{MH}$. This was followed by describing the scope of the present session.

2. Photographs and paintings were of artists, obtained from the Literature, Arts and Medicine database. The activities undertaken by students were; 'What do you see' and 'what do you feel' about the painting or the photograph, in approximately 50 words.

3. We asked the students to analyze the negative perceptions about medical care givers among general public. The next step was to ask the students to reflect and explore the reasons for this negative image.

4. The session ended by asking for commitment on their part to behave in a more ethical and professional manner and develop good communication skills once they start practicing medicine.

5. Feedback was obtained about the activity. We requested the students to participate in a confidential, post discussion questionnaire. The participation was voluntary. The questionnaire comprised of 15 questions, which were both open ended as well as close ended questions.

6. Participants were asked to rate on a Likert's scale of 1 to 5 their enjoyment of the use of paintings in the project, their perception regarding the usefulness of the paintings and photographs and how useful they felt

The median score was calculated for each statement and compared among male and female students using appropriate nonparametric tests $(\mathrm{p}<0.05)$.

7. Four batches of 15 students posted in emergency medicine for 2 weeks were subjected to participate in the pilot project after obtaining consent. The time was between $2 \mathrm{pm}$ to $4 \mathrm{pm}$. Annexure 1 presents the visuals with brief description.

Paintings used are described and embedded in annexure I. The questionnaire was tested for readability andease of understanding of $6^{\text {th }}$ semester students. The demographic information collected was gender, age, and medium of education. The comments for each question in the questionnaire were grouped together into similar headings and the number of times each comment or a comment similar to one already stated occurred was noted. Qualitative analysis was used using MS. Excel.

\section{Results. (Annexure 2)}

Fifty-eightstudents participated. Eighteen students (31\%) were male and forty were female. 
The anatomy dissection painting was easily identified; it was eye catching and dark nature of painting. 67.4 respondents were correct. 50\% students observed the dead mother and child not ready to believe in great depth. The terrorist attack on Taj was perceived as a message of hatredness, loss of peace, people and property by 52\%.(Table 1 shows observation of all visuals) The most common overall comments about the use of paintings were "I could feel what I saw" (18 respondents), "enjoyed the sessions" (18 respondents), "some paintings were hard to interpret" (12 respondents). Suggestions to make annotations about paintings more useful were to make them shorter and more Precise'. Twenty-one students (36\%) had difficulty with the exercise 'what do you feel'. 56\% (33students) enjoyed the session on Likert's scale of 4 to 5. (Table 2). 39 students (67.24\%) found it a useful way of monitoring visual skills or observational power of an individual as it helped them to explore creativity, improve imagination and thinking, express their feeling, heightens emotions and a way of expression ( Table 3). Advantages expressed in learning through painting is depicted in Rabble 4. Median Scores as per gender were not relevant.

\section{Discussion}

The project and the activity was a new experience to the students. Overall opinion about the visuals - photographs and paintings was positive. The paintings aroused and helped them to see and feel andwere generally understandable and enjoyable. Students identified the photographs and paintings but expressing " what you feel” was at times difficult to express. Expression was not easy. Drawing and arts and Humanities in general do not get the attentionthey deserve in school.

Also the top performers in school usually opt for the science

Stream and the 'arts' stream are lookeddown upon as students with a weaker academic performance. Imagination will be usefulin putting oneself in the position of another person andindirectly improving empathy. Creative thinkingmay help developing skills of understanding inthe patient perspective ofsickness. Later a better doctor-patient relationship may develop. Art has been used to improve empathyand identifying with and improvingcompassion towards the sufferer in the west [5]. The effectiveness of arts-based interventions in medical education is well documentedin west but the development of medical humanities in Southeast Asia is a relatively recent phenomenon 10]. In Table 4 the stated advantages of paintings were: alleviating empathy and feelings, the activity was creativeand increased thinking capacity. Our observations were in accordance to Asian study at Nepal [8].

The questionnaire focused on many aspects of use of photographs and paintings in the pilot project with objectivesof only as a small but important portion. Confidential student feedbackwas taken at the end of session. Feedback suggested that to some extent the objectives were met. The students will be followed through clinical postings and internship to see the impact longitudinally.

\section{Conclusions}

Instilling and percolating Medical humanities in medical students as a part of curriculum has already started in Asian region. Participant response was positive and they were satisfied with use of Photographs and paintings in the study. These are easily available. Use of more paintings from Asia and India can be considered. Free imagination, critical thinking, observational skills, expression of thought, non verbal as well as verbal communication are all needed from time to time. Further larger group and longitudinal follow up studies may be required to understand whether use of these visuals succeeded in fulfilling study objectives.

Key words: Medical humanities, visuals, and feedback.

\section{References}

[1]. American Society for Bioethics and Humanities. Purpose of the ASBH. Available at: www.asbh.org/about/purpose.htm

[2]. Costa, P., Magalhães, E. \& Costa, M.J. A latent growth model suggests that empathy of medical students does not decline over time. Adv in Health SciEduc (2013) 18: 509. doi:10.1007/s10459-012-9390-z 
Texila International Journal of Psychology

Volume 1, Issue 2, Dec 2016

[3]. Downie RS, Macnaughton J. Clinical judgement: evidence in practice. Oxford, Oxford University Press, 2000.

[4]. General Medical Council. Tomorrow's doctors: recommendations on undergraduate medical education. London: GMC, 1993.

[5]. Kirklin D. The Centre for Medical Humanities, Royal Free and University College Medical School, London, England. Acad Med. 2003; 78:1048-53.

[6]. Macnaughton J. The humanities in medical education: context, outcomes and structures. J Med Ethics: Medical Humanities 2000;26:23-30

[7]. NunesP, Williams S, Sa B, Stevenson K. A study of empathy decline in students from five health disciplines during their first year of training. International Journal of Medical Education. 2011; 2:12-17. http://creativecommons.org/licenses/by/3.0

[8]. Shamlar PR, Piryani RM, Thapa TP, Karki BM. Our experiences with 'Sparshanam', a medical humanities module for medical students at KIST Medical College, Nepal. J Clin Diag Res. 2010;4: 2158-62.

[9]. Shankar PR. A voluntary medical humanities module in a medical college in Western Nepal: participant feedback. Teach Learn Med. 2009;21:248-53.

[10]. Shah N and Aly SM. Teaching of medical humanities in medical universities of Pakistan $J$ Pak Med Assoc. Vol. 65, No. 4, April 2015

\section{ANNEXURE 1}

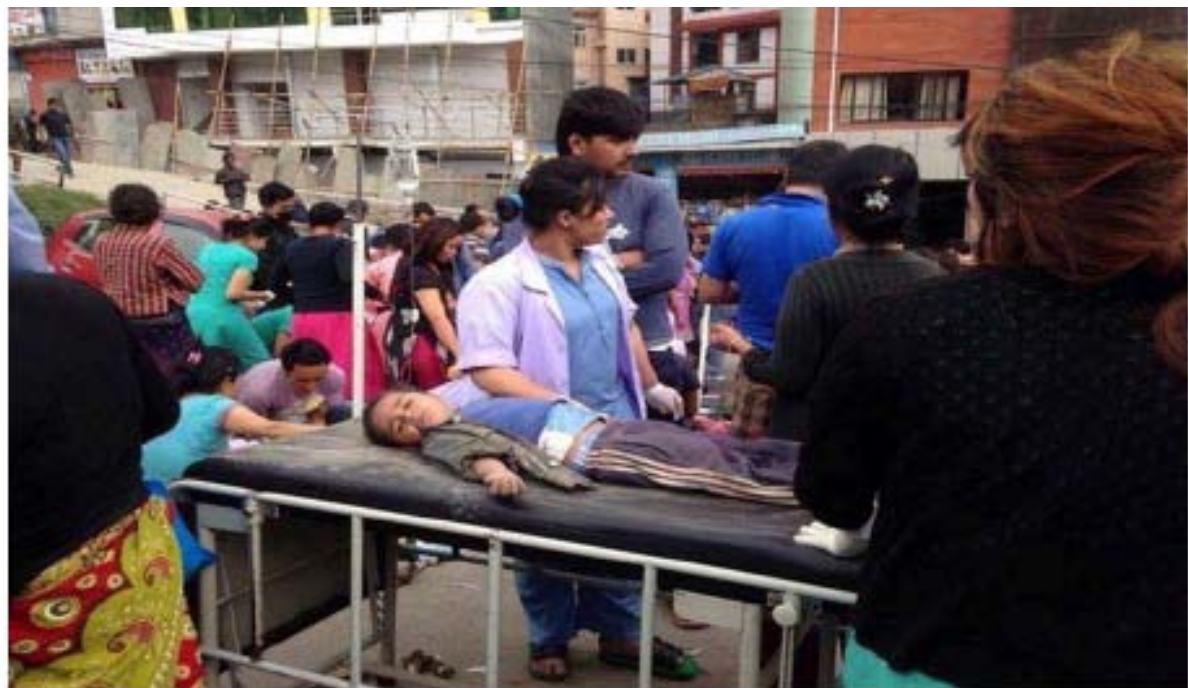

Fig.1 Post disaster earthquake primary health care 


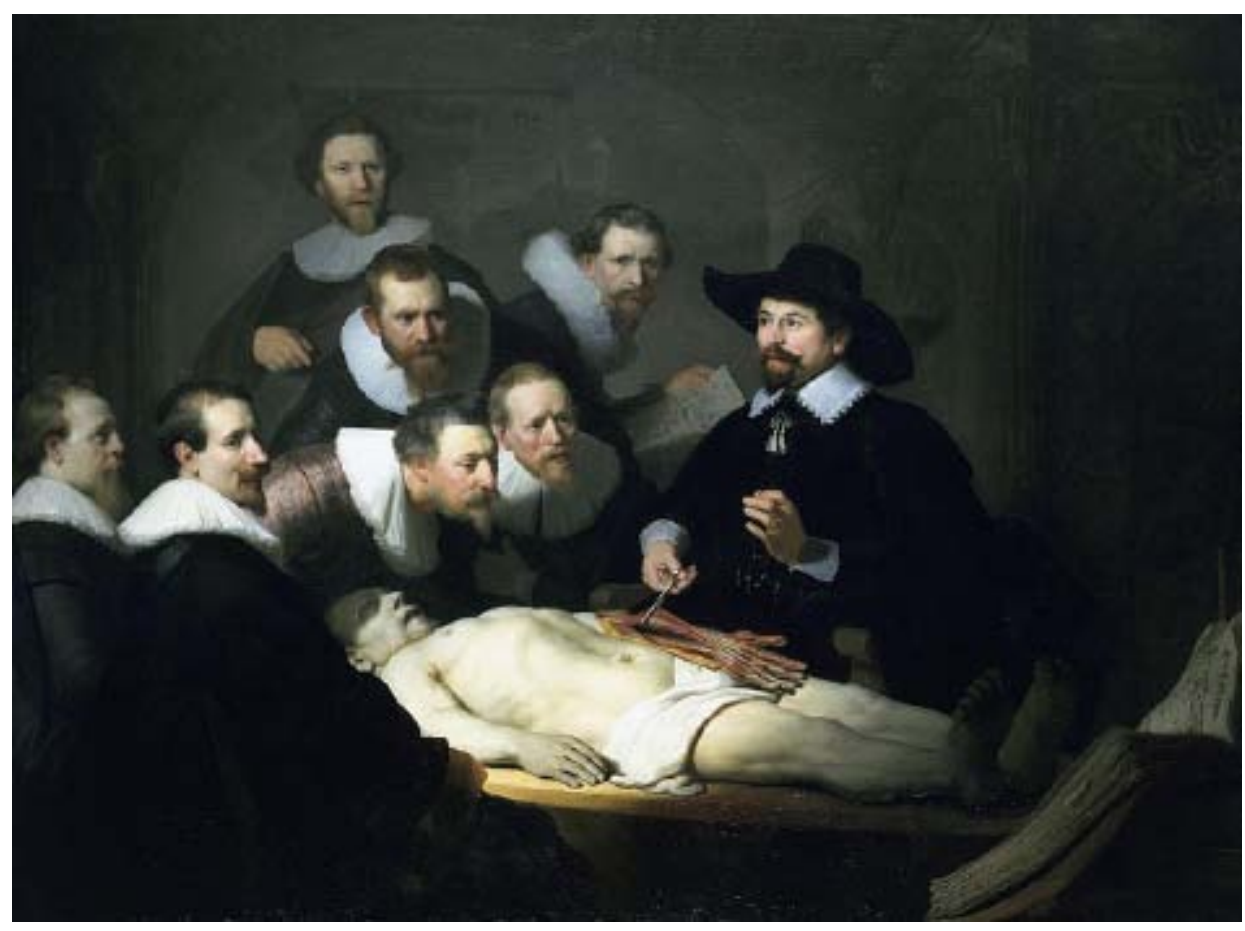

Fig 2. Visual arts - anatomy dissection

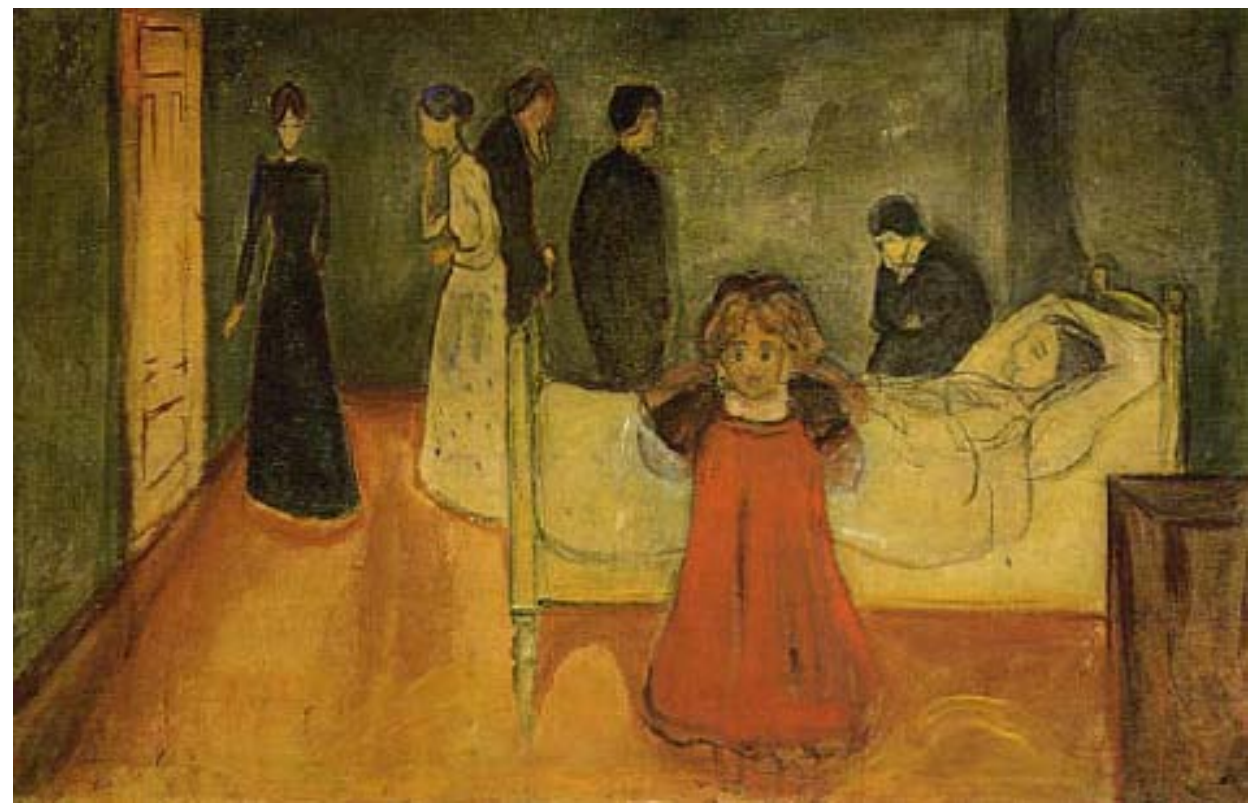

Fig 3. Dead Mother and child refusing to believe. 
Texila International Journal of Psychology

Volume 1, Issue 2, Dec 2016

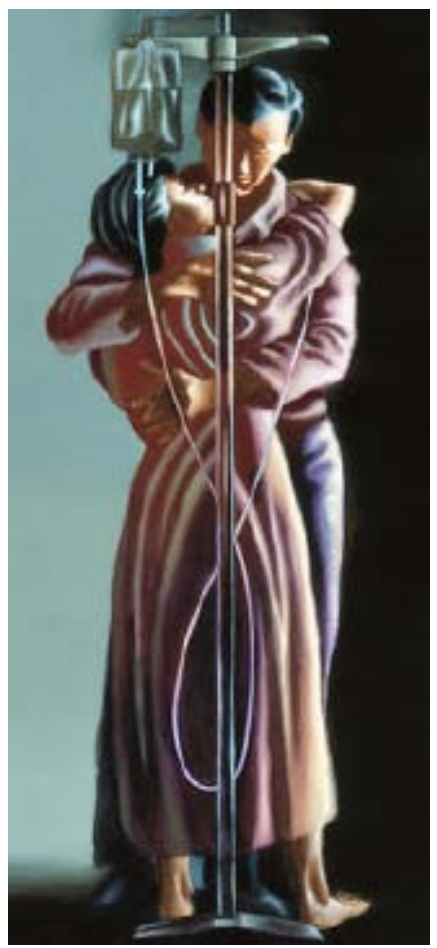

Fig. 4 "Hug," the clasping patient and caregiver

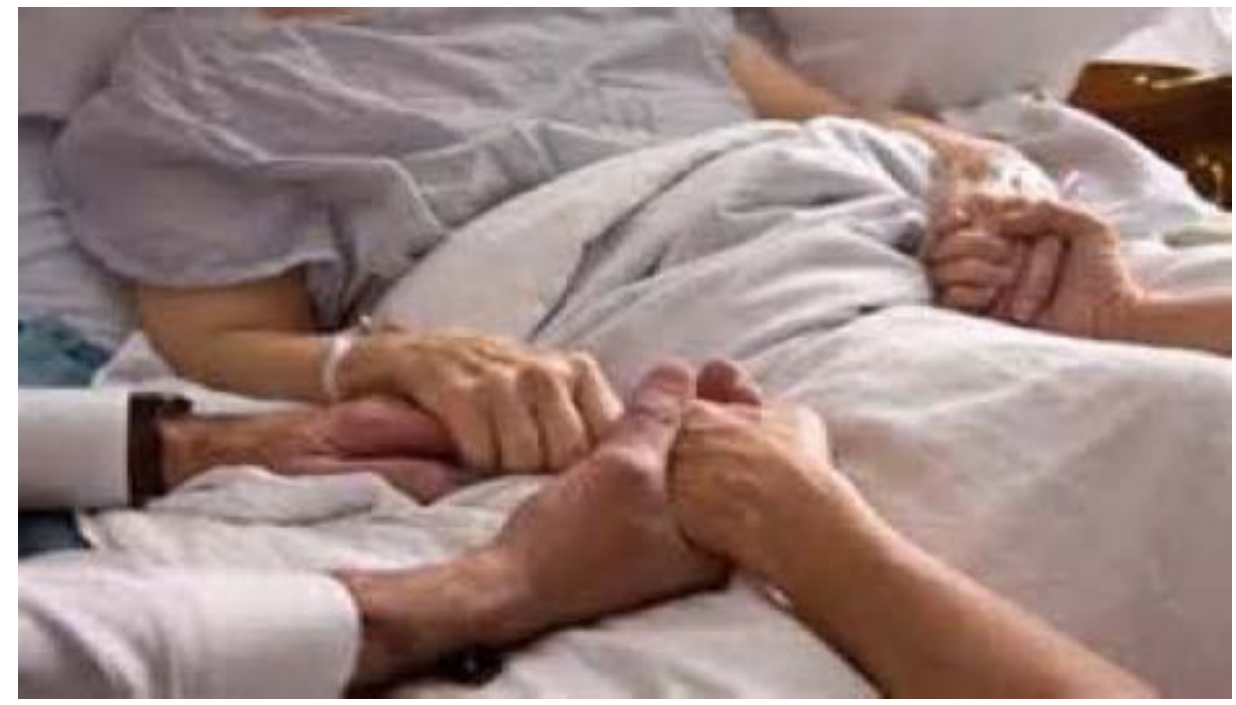

Fig. 5 Sick and fear of loosing 


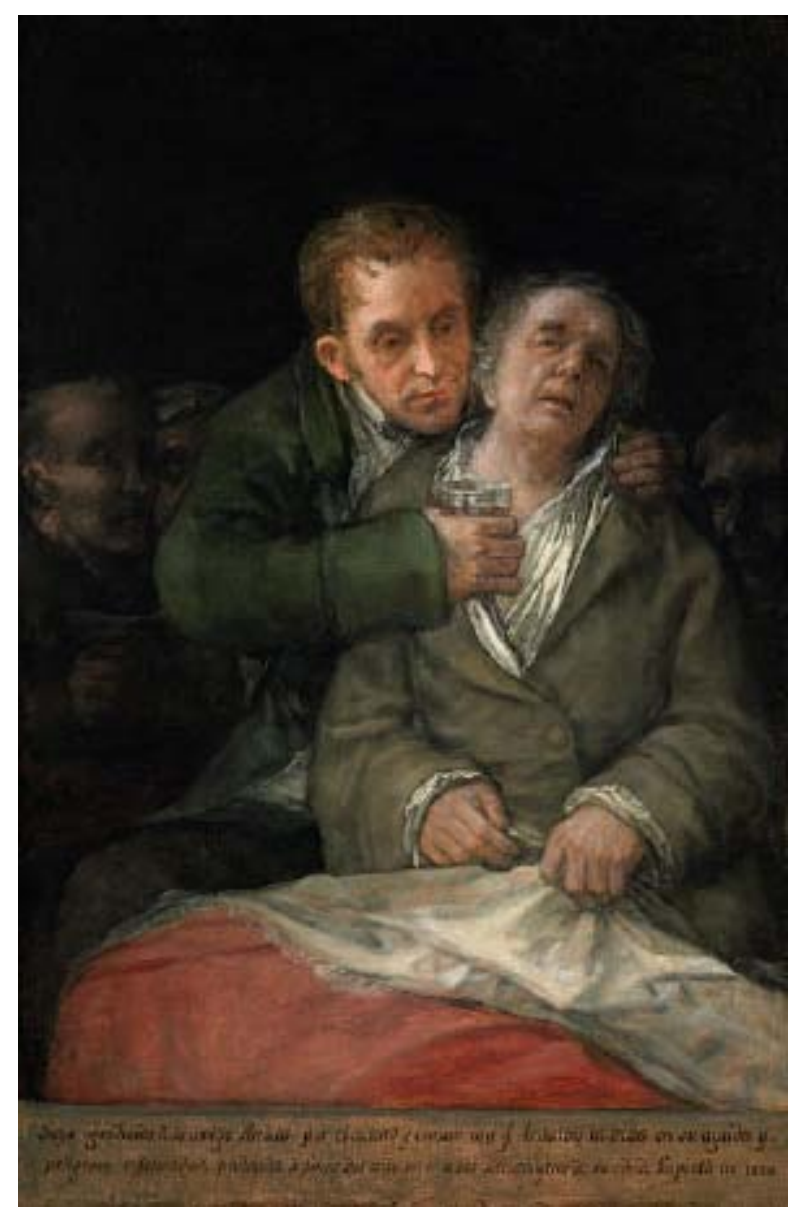

Fig 6. Goya with Dr Arrieta

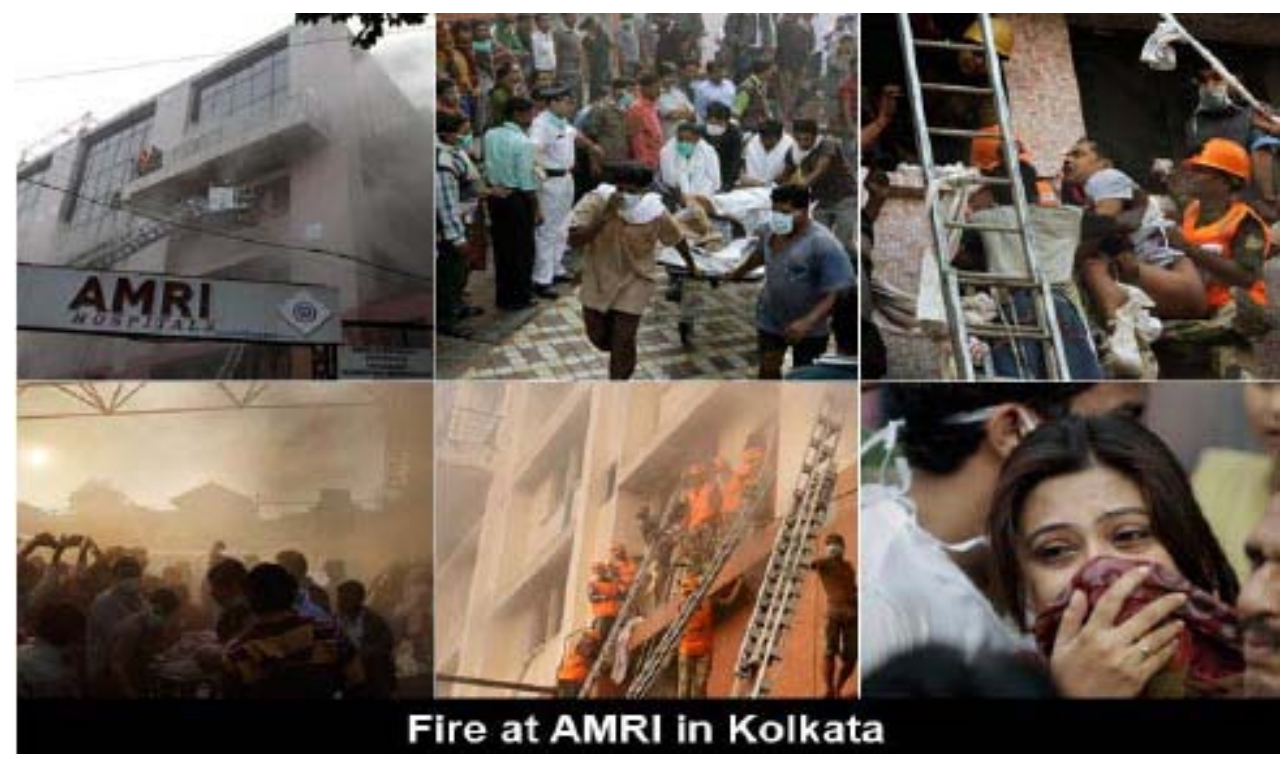

Fig 7. Fire at AMRI Hospital Kolkata 
Texila International Journal of Psychology

Volume 1, Issue 2, Dec 2016

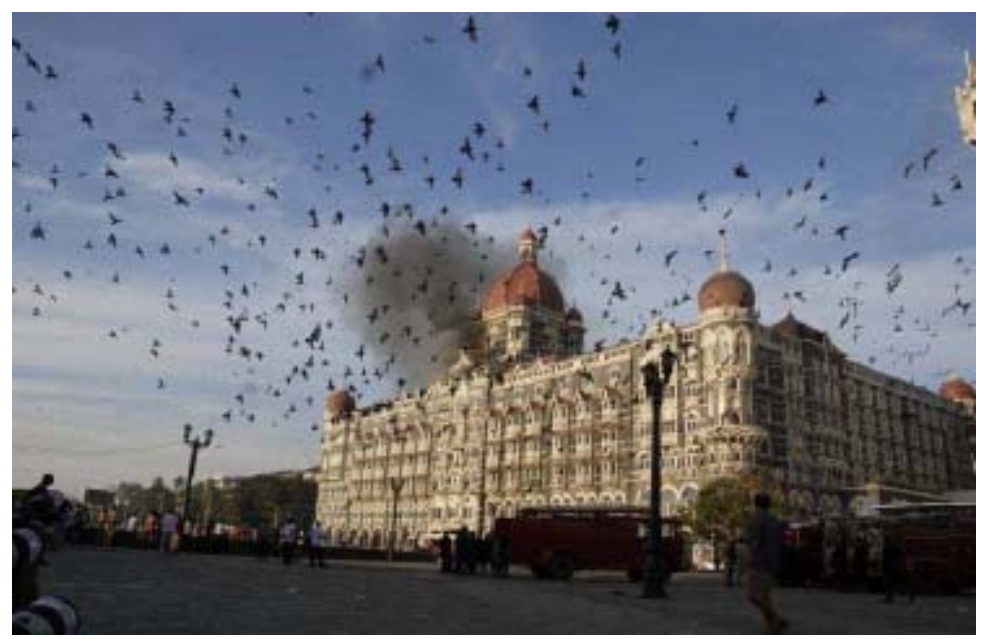

Fig 8. 26/11 Taj on Fire- Terrorist attack

\section{Annexure 2}

\section{Results}

Table 1. Paintings with which students identified the most N-58

\begin{tabular}{|l|c|l|}
\hline \multicolumn{1}{|c|}{ Painting } & Number of respondents & \multicolumn{1}{|c|}{ Reasons } \\
\hline Anatomy lesson & $39(67.24 \%)$ & $\begin{array}{l}\text { Eye catching, dark nature of } \\
\text { painting, } \\
\text { pain of the patient }\end{array}$ \\
\hline Mother and child & $29(50 \%)$ & $\begin{array}{l}\text { Child not ready to hear loss of } \\
\text { mother }\end{array}$ \\
\hline Taj on terrorist attack & $30(51.74 \%)$ & $\begin{array}{l}\text { Loss of peace, people, property. } \\
\text { Message of hatredness }\end{array}$ \\
\hline Patient in ICU & $41(70.68 \%)$ & Fear of loosing all \\
\hline $\begin{array}{l}\text { School students terrorist } \\
\text { attack }\end{array}$ & $25(43.10)$ & These are painful situation \\
\hline Earthquake and firstaid & $32(55.17)$ & Preparedness required \\
\hline
\end{tabular}

Table 2. On Likert's scale liking N-58

\begin{tabular}{|l|c|c|c|c|c|c|}
\hline & $\mathbf{1}$ & $\mathbf{2}$ & $\mathbf{3}$ & $\mathbf{4}$ & $\mathbf{5}$ & NR \\
\hline $\begin{array}{l}\text { Do you enjoy the use } \\
\text { of paintings in the } \\
\text { session }\end{array}$ & - & $\begin{array}{c}12 \\
(20.68 \%)\end{array}$ & $13(22.41 \%)$ & $27(46.55 \%)$ & $6(10.34 \%)$ & \\
\hline $\begin{array}{l}\text { How would you rate } \\
\text { the use of paintings in } \\
\text { the module }\end{array}$ & - & $8(13.79)$ & $10(17.24)$ & $23(39.65)$ & $9(15.51)$ & $8(13.79)$ \\
\hline
\end{tabular}


Table 3. Respondents' perception about the activity create a story of 50 words and feeling of usefulness N-58

\begin{tabular}{|l|c|l|}
\hline \multicolumn{1}{|c|}{ Perception } & $\begin{array}{c}\text { Number of respondents } \\
\text { (percentage) }\end{array}$ & Reasons (in decreasing order of frequency) \\
\hline Useful & $39(67.24 \%)$ & $\begin{array}{l}\text { analyzing humanity } \\
\text { Helps in creatively exploring one's talents } \\
\text { Improves thinking \& imagination } \\
\text { heightens emotions } \\
\text { Nice way to express feelings } \\
\text { Interesting way of learning } \\
\text { Arouses professionalism }\end{array}$ \\
\hline Not useful & $9(15.51 \%)$ & \\
\hline No response & $10(17.24)$ & \\
\hline
\end{tabular}

Table 4. Advantages of learning using paintings for medical students

\begin{tabular}{|l|c|}
\hline \multicolumn{1}{|c|}{ Stated Advantage } & $\begin{array}{c}\text { Number of } \\
\text { respondents }\end{array}$ \\
\hline Promotes empathy \& feelings & 23 \\
Creative \& enjoyable activity & 17 \\
Increases thinking capacity & 10 \\
Provides opportunity to share ideas with group & 7 \\
Sensitizes students to future scenarios & 7 \\
Underlines importance of doctor-patient relationship & 6 \\
Improves power of imagination & 6 \\
Refreshing break from theory classes & 6 \\
Promotes lateral thinking & 5 \\
\hline
\end{tabular}

Table 5. Median scores of specific parameters according to gender

\begin{tabular}{|l|c|c|c|}
\hline \multicolumn{1}{|c|}{ Parameter } & Male & Female & P value \\
\hline $\begin{array}{l}\text { Enjoyment of } \\
\text { paintings }\end{array}$ & 4 & 4 & 0.916 \\
\hline $\begin{array}{l}\text { Usefulness of } \\
\text { annotations }\end{array}$ & 4 & 4 & 0.148 \\
\hline $\begin{array}{l}\text { Usefulness of } \\
\text { paintings }\end{array}$ & 4 & 4 & 0.493 \\
\hline
\end{tabular}

